\title{
Interest and Apprehension to Learn Oral Filipino Language among Selected Foreign Students
}

\author{
Laura O. De Guzman, PhD
}

\begin{abstract}
This descriptive-correlation study aimed at determining the interest and apprehension to learn filipino language among thirty (30) foreign students in UPHSL. Based on the findings, the following conclusions were drawn: Majority of the respondents were male, African and stayed in the Philippines for 4 years and above. Majority agreed that they are now able to speak Filipino language. Majority agreed that They are tense and nervous while participating in group discussions in Filipino. The respondents' level of interest to learn Filipino language is the same regardless of their age, country of origin and length of stay in the Philippines. The respondents' level of apprehension to learn Filipino language is the same regardless of their age, country of origin and length of stay in the Philippines. The respondents level of apprehension is not dependent on their level of interest to learn Filipino language.Based on the conclusions, the following future directions were drawn: Educators should have a better understanding of their learners and should help students cultivate and raise awareness of language learning strategies. Educators have been implicitly teaching language learning strategies with the different classroom activities. We need more Filipinos, who will devote their full time to the scientific study of Philippine languages and dialects. Researchers should investigate more on issues connected to oral communication apprehension. A possible focus of the future research can also be exploring the psychological, instructional, and socio-cultural factors.
\end{abstract}

Keywords: Interest, Apprehension, Filipino Language, Foreign Students

\section{Introduction}

Language conveys so much more than mere words and their meanings. Every language tells a story of history, culture, tradition, natural disasters, invasions and migrations. Language is how we bring thoughts to life, communicate feelings and find common ground amongst the greatest of differences. Wherever we travel, we always try to learn at least some of the language. By doing so, our relationships with the country and the people around us develop little by little, giving us deeper insight and connection with them (Howe, 2015).

The Philippines is as varied in its landscapes as it is in its people and cultures. Its rich and turbulent history has shaped every part of its existence, from its food, traditions, religion, politics, economy and of course, its languages. To understand a Filipino language is to gain a greater understanding of the Philippines itself.

Instruction has been viewed as the basis for advance and improvement in an inexorably assorted, complex, and globalized society. Customarily, the objective of tutoring is to enable understudies to be arranged for full investment in the public arena. Nonetheless, the effect of globalization clears route for instructive changes that persistently change and test the classrooms to be receptive to 21 st century training.

People who made it to school and procured a degree are anticipating work for a nearby organization as well as for worldwide organization. Because of globalization, singular viewpoints have changed and also the schools' main goal. The coming of globalization is intensifying the effectively confounded issue of country working in the Philippines. One reason is that globalization has not created similar advantages for all ethnic and intrigue bunches in Philippine society. On the off chance that globalization has escalated financial divisions and clashes, this is because of the powerlessness of the Philippine state to actualize strategies setting up the nation for worldwide intensity (Banlaoi, 2009).

Considering the foregoing premises, the researcher aimed at determining if there is a relationship between interest and apprehension to learn filipino language among selected foreign students.

\section{Methods}

This study used the descriptive-correlation design as this was suitable and appropriate for the study. The research design enables the researcher to study the interest and apprehension to learn filipino language among selected foreign student of University of Perpetual Help System Laguna. This method was designed to determine if two or more variables are associated with each other. Descriptive correlation method was used to describe the present behavior or characteristics of a particular population (Bermudo, et al., 2013). 
The researcher administered the questionnaire to selected foreign students of UPHSL. The population of the study is the 30 (thirty) selected foreign students of UPHSL. The instrument was divided into two (2) parts: part 1 covered the level of interest, and part 2 focused on level of apprehension. The researcher considered the questionnaire as the most appropriate data gathering instrument for this descriptive-correlation method of the research study interest and apprehension among selected foreign students of UPHSL. A self-made questionnaire was used for interest and apprehension to learn filipino among selected foreign students. It was a close-ended question to determine the interest and apprehension among selected foreign students. The researcher secured a request letter from the HR Officer to administer the questionnaires on interest and apprehension among selected foreign students. After setting the date, the research conducted the survey.

Specifically, thirty (30) selected foreign students were used as sample size of the study. The survey questionnaire was administered and instructions were carefully explained to the respondents for them to understand the purpose of the survey. The distribution of questionnaire was done and the retrieval followed right after the respondents completely answered the questionnaire assuring then of the result's confidentiality. Tallying and treating of the data immediately followed with the guidance of the statistician. The following statistical tools were used: Percentage distribution was used for the profile of the respondents. Weighted mean, used to determine the (a) level of interest to learn filipino language, and (b) level of apprehension to learn filipino language. Mann-Whitney test and Kruskal-Willis test, used to determine the difference (a)level of interest to learn Filipino Language when they are groupedaccording to profilevariables, and (b) level of apprehension to earn Filipino Language when they are groupedaccording to profilevariables. Pearson-r, used to determine if there is significant relationship between the respondents' level of interest and level of apprehension to learn filipinolanguage.

\section{Results and Discussions}

Table 1. Profile of the Respondents

\begin{tabular}{|l|c|c|}
\hline \multicolumn{1}{|c|}{ Profile } & Frequency & Percentage, $\%$ \\
\hline Gender & 24 & 80.0 \\
Male & 6 & 20.0 \\
Female & & \\
\hline Country of Origin & 23 & 76.7 \\
African & 5 & 16.7 \\
Asian & 2 & 6.7 \\
American & 12 & 40.0 \\
\hline Length of Stay in the Philippines & 18 & 60.0 \\
1-3 years & \multicolumn{2}{|l}{} \\
4 years and above & \\
\hline Total Number of Schools =30
\end{tabular}

Table 1 shows the profile of the respondents, as to gender, male respondents were 24 or $80 \%$ while female respondents were 6 or $20 \%$. As to country of origin, African 23 or $76.7 \%$, Asian 5 or $16.7 \%$ and American 2 or $6.7 \%$. As to length of stay in the Philippines, 1-3 years 12 or $40 \%$ and 4 years and above 18 or $60 \%$.

To sum up, majority of the respondents were male, African and more than half of the respondents were African had been in the Philippines for 4 years and above.

A study of Amogne\&Yigzaw (2012) Difficulties in communicating in English among students are experienced as the language is primarily taught in a foreign language context where students have limited access to it outside the classroom context. Regardless of this, English Language teaching is still one of the central businesses of higher education in Ethiopia.

Table 2. Level of Interest to Learn Filipino Language

\begin{tabular}{|l|c|c|c|}
\hline \multicolumn{1}{|c|}{ Indicators } & $\begin{array}{c}\text { Weighted } \\
\text { Mean }\end{array}$ & Interpretation & Rank \\
\hline $\begin{array}{l}\text { 1. I am interested in learning or studying the studying } \\
\text { the Filipino language }\end{array}$ & 4.24 & High & 5.5 \\
\hline 2. I like to attend my Filipino language class. & 3.91 & High & 8 \\
\hline $\begin{array}{l}\text { 3. My professor provides any materials for the Filipino } \\
\text { workshops and I like it. }\end{array}$ & 4.47 & High & 2 \\
\hline 4. I am now able to speak Filipino language. & 4.53 & Very High & 1 \\
\hline $\begin{array}{l}\text { 5. Friends and classmates are willing to teach me } \\
\text { Filipino language and I enjoy it. }\end{array}$ & 4.38 & High & 3 \\
\hline
\end{tabular}




\begin{tabular}{|l|c|c|c|}
\hline 6. I enjoy coming in to my Filipino language class. & 4.18 & High & 7 \\
\hline $\begin{array}{l}\text { 7. I am now able to write and understand Filipino } \\
\text { language. }\end{array}$ & 4.24 & High & 5.5 \\
\hline $\begin{array}{l}\text { 8. I like to share my knowledge and opinion with friends } \\
\text { in my learnings from my Filipino language class. }\end{array}$ & 4.26 & High & 4 \\
\hline \multicolumn{1}{|c|}{ Average Weighted Mean } & 4.26 & High & \\
\hline
\end{tabular}

Table 2 shows the level of interest to learn Filipino language, indicator no. 6 "I am now able to speak Filipino language." ranked as first interpreted as Very High and obtained a weighted mean of 4.53, indicator no. 3 "My professor provides any materials for the Filipino workshops and I like it." ranked as second, interpreted as High, ranked as third and obtained a weighted mean of 4.47, indicator no. 7 "I am now able to write and understand Filipino language." and Indicator no. 1 "I am interested in learning or studying the studying the Filipino language." ranked both as fifth interpreted as High and obtained a weighted mean of 4.24, Indicator no. 7 "I enjoy coming in to my Filipino language class." ranked as seventh interpreted as High and obtained a weighted mean of 4.18, and lastly, indicator no. 2 "I like to attend my Filipino language class." ranked as eighth, interpreted as High and obtained a weighted mean of 3. 91.

To sum up, an average weighted mean of 4.26 indicated that respondents agreed to have a level of interest to learn Filipino language. Majority agreed that "I am now able to speak Filipino language."

A study of Lee(2010) among these factors, one's learning strategies have been gaining much interest for being identified as a crucial factor in the entire process of language learning as results showed that there is a wider array of strategies being employed by the more successful language learners. Generally, language learning strategies as "behaviors and thoughts that a learner engages in during learning" and are "intended to influence the learner's encoding process".

Table 3. Level of Apprehension to Learn Filipino Language

\begin{tabular}{|l|c|c|c|}
\hline \multicolumn{1}{|c|}{ Indicators } & $\begin{array}{c}\text { Weighted } \\
\text { Mean }\end{array}$ & Interpretation & Rank \\
\hline $\begin{array}{l}\text { 1. I dislike participating in group discussions in } \\
\text { Filipino. }\end{array}$ & 2.73 & High & 2.5 \\
\hline $\begin{array}{l}\text { 2. Generally, I am not comfortable while } \\
\text { participating in group discussions in Filipino. }\end{array}$ & 2.73 & High & 2.5 \\
\hline $\begin{array}{l}\text { 3. I am tense and nervous while participating in } \\
\text { group discussions in Filipino. }\end{array}$ & 2.77 & High & 1 \\
\hline $\begin{array}{l}\text { 4. Generally, I am nervous when I have to } \\
\text { participate in a meeting in Filipino. }\end{array}$ & 2.67 & High & 5 \\
\hline $\begin{array}{l}\text { 5. I am afraid to express myself at meetings in } \\
\text { Filipino subject. }\end{array}$ & 2.70 & High & 4 \\
\hline $\begin{array}{l}\text { 6. Communication at meetings usually makes me } \\
\text { uncomfortable in Filipino. }\end{array}$ & 2.43 & Low & 9 \\
\hline $\begin{array}{l}\text { 7. I am not relaxed when answering questions at a } \\
\text { meeting in Filipino. }\end{array}$ & 2.13 & High & 6 \\
\hline $\begin{array}{l}\text { 8. While participating in a conversation with a new } \\
\text { acquaintance, I feel very nervous in Filipino. }\end{array}$ & 2.57 & Low & 8 \\
\hline $\begin{array}{l}\text { 9. Ordinarily I am very tense and nervous in } \\
\text { conversations in Filipino. }\end{array}$ & 2.47 & High & 7 \\
\hline 10. I'm afraid to speak up in Filipino conversations. & 2.53 & High & \\
\hline \multicolumn{1}{|c|}{ Average Weighted Mean } & 2.57 & "I an \\
\hline
\end{tabular}

Table 3 shows the level of apprehension to learn Filipino language, indicator no. 3 "I am tense and nervous while participating in group discussions in Filipino." ranked as first, interpreted as High, obtained a weighted mean of 2.77; indicator no. 1 "I dislike participating in group discussions in Filipino." and indicator no. 2 "Generally, I am not comfortable while participating in group discussions in Filipino." ranked as second, interpreted as High, obtained a weighted mean of 2.47; indicator no. 9 "Ordinarily I am very tense and nervous in conversations in Filipino." ranked as eighth, interpreted as Low and obtained a weighted mean of 2.24, Indicator no. 6 "Communication at meetings usually makes me uncomfortable in Filipino." interpreted as Low obtained a weighted mean of 2.43, and lastly, indicator no.102 "I am not relaxed when answering questions at a meeting in Filipino." interpreted as Low, obtained a weighted mean of 2.13 . 
To sum up, an average weighted mean of 2.57 indicated that respondents agreed to have a level of interest to learn Filipino language. Majority agreed that "I am tense and nervous while participating in group discussions in Filipino." A study by Kachru (2010) stating that "as well to speak Filipino with others within the global dispora outside the Philippines may also bridge a communication gap, but may also reflect a distinct identity marker, one which creates a social bond between other Filipinos.

Table 4. Difference in the Respondents' Level of Interest to Learn Filipino Language When They Are Grouped According to Profile Variables

\begin{tabular}{|c|c|c|c|c|}
\hline Profile & Mean & Statistical Test & $\mathrm{p}$-value & Interpretation \\
\hline Gender & $\begin{array}{c}\mathrm{X}_{1}(\text { Male })=1.7917 \\
\mathrm{X}_{2}(\text { Female })=1.6042\end{array}$ & $\begin{array}{c}\text { Mann-Whitney } \mathrm{U} \\
\text { Test } \\
\mathrm{U}=49.500 \\
\mathrm{Z}=1.179\end{array}$ & 0.238 & $\begin{array}{c}\text { Not } \\
\text { Significant }\end{array}$ \\
\hline Country of Origin & $\begin{array}{c}\mathrm{X}_{1}(\text { African })=1.8261 \\
\mathrm{X}_{2}(\text { Asian })=1.4500 \\
\mathrm{X}_{3}(\text { American })=1.6875\end{array}$ & $\begin{array}{c}\text { Kruskal-Wallis } \\
\text { Test } \\
\mathrm{X}^{2}=4.669 \\
\end{array}$ & 0.097 & $\begin{array}{c}\text { Not } \\
\text { Significant }\end{array}$ \\
\hline $\begin{array}{l}\text { Length of Stay in } \\
\text { the Philippines }\end{array}$ & $\begin{array}{c}\mathrm{X}_{1}(1-3 \mathrm{yrs})=1.7708 \\
\mathrm{X}_{2}(4 \mathrm{yrs} \text { and above })= \\
1.7431\end{array}$ & $\begin{array}{c}\text { Mann-Whitney } \mathrm{U} \\
\text { Test } \\
\mathrm{U}=96.000 \\
\mathrm{Z}=0.514\end{array}$ & 0.608 & $\begin{array}{c}\text { Not } \\
\text { Significant }\end{array}$ \\
\hline
\end{tabular}

0.05 level of significance

As shown in the table, for the difference in the respondents' level of interest to learn Filipino language when the respondents are grouped according to gender, country of origin and length of stay in the Philippines, $\mathrm{p}$ values of 0.238 , 0.097 and 0.608 , respectively, were obtained which were higher than the 0.05 level of significance. This shows that there is no significant difference in the respondents' level of interest to learn Filipino language when the respondents are grouped according to gender, country of origin and length of stay in the Philippines. The respondents' level of interest to learn Filipino language is the same regardless of their age, country of origin and length of stay in the Philippines.

A study of Thomas \& Healey (2010) For one thing, very few Filipinos at present are interested in linguistics because they think, perhaps not very. correctly, that there is no money in it and also because of the common misconception that linguistics is merely learning to speak many languages. Another reason is that many Western linguists do not seem to be eager or don't have the time to train natives in this part of the world to become linguists. Many Western linguists would rather use the 'natives' or speakers of 'exotic' languages as their informants or data gatherers.

Table 5. Difference in the Respondents' Level of Apprehension to Learn Filipino Language When They Are Grouped According to Profile Variables

\begin{tabular}{|c|c|c|c|c|}
\hline Profile & Mean & Statistical Test & $\mathrm{p}$-value & Interpretation \\
\hline Gender & $\begin{array}{c}\mathrm{X}_{1}(\text { Male })=2.6292 \\
\mathrm{X}_{2}(\text { Female })=2.3500\end{array}$ & $\begin{array}{c}\text { Mann-Whitney } \mathrm{U} \\
\text { Test } \\
\mathrm{U}=47.500 \\
\mathrm{Z}=1.279 \\
\end{array}$ & 0.201 & $\begin{array}{c}\text { Not } \\
\text { Significant }\end{array}$ \\
\hline $\begin{array}{l}\text { Country of } \\
\text { Origin }\end{array}$ & $\begin{array}{c}\mathrm{X}_{1}(\text { African })=2.6348 \\
\mathrm{X}_{2}(\text { Asian })=2.3600 \\
\mathrm{X}_{3}(\text { American })=2.4000\end{array}$ & $\begin{array}{c}\text { Kruskal-Wallis } \\
\text { Test } \\
\mathrm{X}^{2}=1.288 \\
\end{array}$ & 0.528 & $\begin{array}{l}\text { Not } \\
\text { Significant }\end{array}$ \\
\hline $\begin{array}{l}\text { Length of Stay in } \\
\text { the Philippines }\end{array}$ & $\begin{array}{c}\mathrm{X}_{1}(1-3 \mathrm{yrs})=2.4833 \\
\mathrm{X}_{2}(4 \mathrm{yrs} \text { and above })=2.6333\end{array}$ & $\begin{array}{c}\text { Mann-Whitney } U \\
\text { Test } \\
U=81.000 \\
Z=1.151 \\
\end{array}$ & 0.250 & $\begin{array}{c}\text { Not } \\
\text { Significant }\end{array}$ \\
\hline
\end{tabular}

0.05 level of significance

As shown in the table, for the difference in the respondents' level of apprehension to learn Filipino language when the respondents are grouped according to gender, country of origin and length of stay in the Philippines, $\mathrm{p}$ values of 0.201 , 0.528 and 0.250 , respectively, were obtained which were higher than the 0.05 level of significance. This shows that there is no significant difference in the respondents' level of apprehension to learn Filipino language when the respondents are grouped according to gender, country of origin and length of stay in the Philippines. 
The respondents' level of apprehension to learn Filipino language is the same regardless of their age, country of origin and length of stay in the Philippines. A study of Horwitz (2010) stated that when she pointed out that language anxiety might be caused by fear of social evaluation as one of the three performance anxieties together with communication apprehension and test anxiety, supports this finding.

Buss (2005), mentioned in McCroskey (2010), identifies factors that may contribute to increased communication apprehension that include novelty, formality, subordinate status, conspicuousness, unfamiliarity, dissimilarity, and degree of attention from others. The most important factors that could lead an oral communicator's performance into a failure are low intellectual skills, speech skill deficiencies, voluntary social introversion, social alienation, communication anxiety, low social self-esteem and ethnic/cultural divergence in communication norms.

\section{Table 6. Relationship Between the Respondents' Level of Interest and Level of Apprehension to Learn Filipino} Language

\begin{tabular}{|l|c|c|l|}
\hline \multicolumn{1}{|c|}{ Variables } & Pearson $\mathrm{r}$ & $\mathrm{p}$ value & \multicolumn{1}{|c|}{ Interpretation } \\
\hline $\begin{array}{l}\text { Level of Interest and Level of } \\
\text { Apprehension to Learn Filipino Language }\end{array}$ & 0.008 & 0.965 & $\begin{array}{l}\text { Not } \\
\text { Significant }\end{array}$ \\
\hline
\end{tabular}

0.05 level of significance

As shown in the table, for the relationship between the respondents' level of interest and level of apprehension to learn Filipino Language, a p value of 0.965 was obtained which was higher than the 0.05 level of significance. This shows that there is no significant difference in the respondents' level of interest and level of apprehension to learn Filipino language. The respondents' level of apprehension is not dependent on their level of interest to learn Filipino language.

A study of Chen \& Lin (2009) Throughout the years, various research have ventured on determining the various factors that may positively or negatively affect the process of language learning. From teacher- focused classroom research, there has been a shift of interest to student-centered variables affecting language learning of both foreign and second language speakers. A number of these carefully undertaken studies focus on variables such as motivation, level of anxiety willingness to communicate and significantly, language learning strategies.

\section{Conclusions}

Based on the findings, the following conclusions were drawn: Majority of the respondents were male, African and stayed in the Philippines for 4 years and above. Majority agreed that they are now able to speak Filipino language. Majority agreed that they are tense and nervous while participating in group discussions in Filipino. The respondents' level of interest to learn Filipino language is the same regardless of their age, country of origin and length of stay in the Philippines.The respondents' level of apprehension to learn Filipino language is the same regardless of their age, country of origin and length of stay in the Philippines. The respondents' level of apprehension is not dependent on their level of interest to learn Filipino language.

\section{Future Directions}

Based on the conclusions, the following future directions were drawn: Educators should have a better understanding of their learners and should help students cultivate and raise awareness of language learning strategies. Educators have been implicitly teaching language learning strategies with the different classroom activities. We need more Filipinos, who will devote their full time to the scientific study of Philippine languages and dialects. Researchers should investigate more on issues connected to oral communication apprehension. A possible focus of the future research can also be exploring the psychological, instructional, and socio-cultural factors.

\section{References}

Amogne, D. \&Yigzaw, A. (2012) Oral communication apprehension, competence and performance among maritime engineering trainees. Journal of Media and Communication Studies Vol. 5(1), pp. 5-11, January 2013

Banlaoi, A. (2009) .The significance of language exposure with writingself-efficacy andwriting apprehension of Filipino ESL writers. Philippine ESLJournal, 10, 232-244.

Bermudo, P., Araojo, A., Morales, M., \&Yango, A. (2013). Research Writing Made Simple: A Modular Approach for Collegiate and Graduate Students p6

Buss, J (2005). Oral Communication Apprehension: A Summary of Recent Theory and Research. Human Commun. Res. 4(1) 
Chen, M. C. \& Lin, H. J. (2009). Self-efficacy, foreign language anxiety as predictors of academic performance among professional program students in a general English proficiency writing test. Perceptual and Motor Skills $109(2), 420-430$.

Howe, J. (2015). 5 reasons why foreigners should learn Filipino languages. Retrieved May 2018 from http://www.gmanetwork.com/news/lifestyle/artandculture/535039/5-reasons-why-foreigners-should-learnfilipino-languages/story/

Horwitz, E. K. (2010). Recent research on second language learners: Belief and anxiety. Texas Papers on Foreign Language Education, 3, 51-60.

Kachru, B. (2010). The Indianization of English: the English language in India. NewYork, NY: Oxford University Press.

Lee, R.(2010). Language anxiety: From theory and research to classroom implications. Englewood Cliffs, NJ: Prentice Hall.

McCroskey, J. C. (1984). The Communication Apprehension Perspective. In Avoiding Communication: Shyness, Reticence, and Communication Apprehension. J. A. Daly and J. C. McCroskey, eds. Beverly Hills: Sage Publications.

Thomas, D. \& Healey, A. (2010). "Some Philippine Language Subgroupings: A Lexicostatistieal Study," Anthropoboqical Linguistics, 4 (December 1962), 22-33. 